Original Research Paper

\title{
Structure and Diversity of Agroforestry Parklands in the Sudano-Sahelian Zone of Cameroon
}

\author{
1*Awé Djongmo Victor, ${ }^{1,2}$ Noiha Noumi Valery and ${ }^{3}$ Zapfack Louis \\ ${ }^{1}$ Department of Biological Sciences, Faculty of Science, University of Ngaoundere, P.O. Box 454, Ngaoundere, Cameroon \\ ${ }^{2}$ Department of Life Science, Higher Teacher Training College of Bertoua, University of Ngaoundere, \\ P.O. Box 652, Bertoua, Cameroon \\ ${ }^{3}$ Department of Biology and Plant Physiology, Faculty of Sciences, University of Yaoundé I, \\ P.O. Box 812, Yaoundé, Cameroon
}

Article history

Received: 17-08-2020

Revised: 03-11-2020

Accepted: 13-11-2021

Corresponding Author:

Awé Djongmo Victor

Department of Biological

Sciences, Faculty of Science, University of Ngaoundere, P.O.

Box 454, Ngaoundere,

Cameroon

Email: awevictor20@yahoo.fr

\begin{abstract}
The general objective of the study is to characterize the woody vegetation of 05 agroforestry parkland in the Sudano-Sahelian zone of Cameroon. A total of 40 floristic surveys of $200 \times 20 \mathrm{~m}$ were carried out. A total of 33 species in 20 families and 31 genera were recorded. The dendrometric survey method enabled us to characterize the vegetation of the agroforestry parks. The dendrometric parameters and indices calculated according to the agroforestry parks vary from one park to another. Thus, density varies from $108 \pm 2.98-223 \pm 8.01$ individuals/ha, recovery from $6.11 \pm 0.21-10.12 \pm 0.31 \%$, basal area from $6.54 \pm 1.12$ to $10.05 \pm 1.87 \mathrm{~m}^{2} / \mathrm{ha}$, biovolume from $20.09 \pm 2.22-38.54 \pm 3.76 \mathrm{~m}^{3} / \mathrm{ha}$, total height from 2.11 $\pm 0.01-5.06 \pm 0.04 \mathrm{~m}$, natural regeneration rate from 2.11 \pm 0.52 $7.40 \pm 1.09 \%$. The Shannon index varies from $1.36 \pm 0.20-2 \pm 0.29$ bits, Pielou index from $0.14 \pm 0.07-0.35 \pm 0.18$ and Simpson index from $0.82 \pm 0.02-0.97 \pm 0.03$. The species with the highest SIV and SIR are Combretum glutinosum, Combretum adenogonium, Sclerocarya birrea, Prosopis africana, Entada africana, Anacardium occidentale, Burkea africana, Maytenus senegalensis, Ficus glumosa. The Mimosaceae, Caesalpiniaceae, Combretaceae show a high representativeness in relation to their family importance value. The diameter structure showed a predominance of young individuals and the height structure showed a predominance of individuals of class [4-6 m]. These results can be used as a reference in monitoring the vegetation dynamics of agroforestry parks subject to recurrent droughts and anthropogenic pressures. This study provides a better understanding of the vegetation in agroforestry parks in order to better manage these plant resources.
\end{abstract}

Keywords: Agroforestry Parklands, Structure, Floristic Composition, Cameroon

\section{Introduction}

During these two decades, the sub-Saharan Africa is facing an accelerated degradation of its plant biodiversity as a result of anthropogenic activities and naturally (FAO, 2015). The climate warming on the planet is a major challenge for developing countries (FAO, 2015; Noumi et al., 2018). The populations living in these countries depend heavily on natural resources of plant and often have an adaptive capacity relatively limited (FAO, 2015). Therefore, these countries are often among the most seriously affected by climate change. In Cameroon, as in several other countries in sub-Saharan Africa, the effects of climate change are more than ever noticeable, especially in the region of Sudano-Sahelian (FAO, 2015; Victor et al., 2020b). Several scientific works provide that climate change will affect the livelihoods and the plant biodiversity of significantly (Kabore et al., 2013; Rabiou et al., 2015).

African forest ecosystems are recognized as among the most important and richest in terms of abundance and diversity of plant species (Victor et al., 2020b). They play a crucial role in sustaining life on the planet (Kabore et al., 2013). They intervene in the regulation of 
global and regional climate systems (FAO, 2015). Despite these multiple functions, the management of natural forests, particularly in sub-Saharan Africa, is confronted with a lack of data to enable the functioning of these ecosystems to be understood in terms of floristic composition, demographic structure and regeneration (Rabiou et al., 2015). However, the recurrence of rainfall deficits in recent decades has caused a decline in food production based essentially on rainfed agriculture (FAO, 2015). Natural ecosystems are therefore subject to increased exploitation by a galloping population growth seeking food supplements and sources of income (Froumsia et al., 2012; Mouhamadou et al., 2013).

The Sahelian zone is characterized by an ecological fragility, an increase of the acidification for the medium and high mortality of woody plants with a decrease in biological diversity (Noumi et al., 2018). This area is little industrialized and populations consisting to majority of agro-pastoralists, located in the woody stratum the supplementary foods, drugs, the sources of energy, the fodder for their animals and the materials necessary for the manufacture of objects in current use. The concern for biodiversity conservation, taking into account the needs and aspirations of local populations, has become real since the Earth Summit in 1992 (Mouhamadou et al., 2013). Plant species in Africa are very important to human populations because of their contribution to meeting the needs for food, health, energy, income and other aspects of human well-being (Mouhamadou et al., 2013). Despite this recognized importance of collective consciousness, the erosion of biodiversity continues and constitutes a threat to humanity (Mouhamadou et al., 2013). Thus, the ligneous plants and their habitats are subjected to disturbances, linked to these anthropogenic actions and to climate change, which threaten their survival even though their ecological, morphological, genetic characterizations and the inventory of their usefulness have not been deepened (Noumi et al., 2018; Victor et al., 2020b).

Forest ecosystems are extremely rich in plant and wildlife species that are sometimes little or poorly known. However, the increasing trend in the current rate of deforestation, especially in tropical areas (FAO, 2015), may lead to the erosion of some as yet unknown forest species. Indeed, the lack of quantitative information on the abundance and distribution of tropical organisms remains a problem for biodiversity conservation and sustainable management of forest ecosystems. As a result, it becomes difficult to know which species is the most threatened (Froumsia et al., 2012; Mouhamadou et al., 2013). The alarming rate of degradation of forest ecosystems in the tropics is leading directly to the fragmentation of plant formations. Man, who has not been able to find a balance between his exploitation system and the resilience of the natural environment, remains the main agent of the regressive evolution of ecosystems (FAO, 2015). Through cultivation, forestry, the expansion of livestock farming and hunting, man is conquering an ever-increasing part of the space. The degradation of ecosystems today constitutes a threat to biodiversity, as the destruction of natural environments inevitably leads to the scarcity or even disappearance of species (Victor et al., 2020b). The growing needs of populations, bush fires and drought have caused an increasingly marked degradation of these habitats. This is manifested by changes in the floristic composition and structure of vegetation, poor natural regeneration of some species and bare soil due to erosion, a factor of impoverishment. However, given the relatively low level of knowledge about agroforestry parks, the question "What is the contribution of agroforestry systems to the development of rural communities" arises.

A. leiocarpus, I. doka, T. laxiflora, P. thonningii and A. digitata are agroforestry species that occupy an important place due to their multiple roles. These agroforestry parks play an important role in food and economic security, providing "fuel, food, medicinal products, fodder and various service products", while protecting the physical environment (Arbonnier, 2004). Tree densities are low to medium (discontinuous tree cover) and livestock production is sometimes associated with them. The objectives of this study are to study the diversity and structure of agroforestry parks in the Sudano-Sahelian zone of Cameroon.

\section{Materials and Methods}

\section{Study Area}

The study was carried out in the north region of Cameroon. This region is located between $9^{\circ} 18^{\prime} \mathrm{N}$ to $8^{\circ} 10^{\prime} \mathrm{N}$ latitude and $13^{\circ} 23^{\prime} \mathrm{E}$ to $12^{\circ} 16^{\prime} \mathrm{E}$ longitude (Victor et al., 2019a) Fig. 1. The north Cameroon region has a tropical climate in the Sudano-Sahelian type. The relief is a vast pediatric plain between the Mandara Mountains $(1,442 \mathrm{~m})$ in the North and the Adamawa Plateau in the South. The soil is of ferruginous type formed by degradation of sandstone from the Middle Cretaceous (Victor et al., 2020a). The vegetation encountered is a shrubby Sudanian savannah with a clear and degraded savannah appearance (Victor et al., 2020b). The fauna is rich and very diverse (Victor et al., 2019b). Economic activities concern: Agriculture, animal husbandry, fishing, social economy and handicrafts, transport and trade. Agriculture is the main activity of the populations of the North Cameroon region. 

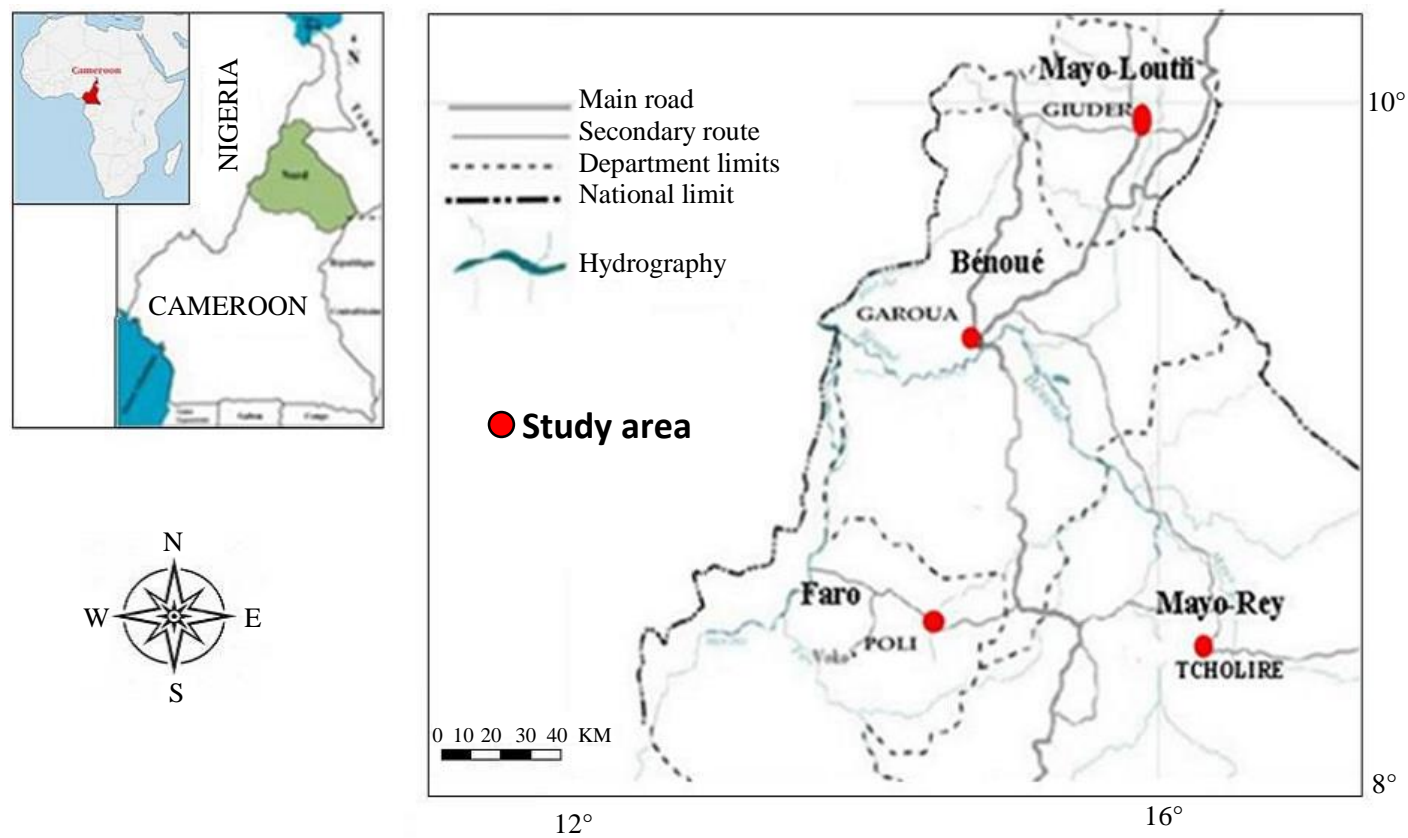

Fig. 1: Geographic location of the study area in North Cameroon Region

\section{Data Collection}

\section{Criteria for the Selection of Agroforestry Parkland}

The socio-economic and environmental importance, density, availability, topography and size of A. leiocarpus, I. doka, T. laxiflora, $P$. thonningii and A. digitata agroforestry parkland were the main reasons for the choice of these species for their structural and floristic analysis.

\section{Sampling Methods}

Sampling methods consist of transects ranging from $200 \mathrm{~m}$ long to $20 \mathrm{~m}$ wide. These transects were laid out in a north-south direction to cover most or all of the agroforestry parks studied. Sampling strips were established using wire and compass. At the ends of each strip, stakes were marked $10 \mathrm{~m}$ equidistant from the base. At each $10 \mathrm{~m}$ distance, all trees were inventoried. The geographic coordinates of each tree in the sample were collected using GPS to determine its geographic position in the field. All trees were systematically counted and measured. The dendrometric data were based on Diameter at breast height (Dbh), height and trunk size. For example, the circumference of trees was measured with a tape measure at $1.3 \mathrm{~m}$ from the ground for large trees and at $50 \mathrm{~cm}$ from the ground for shrubs and bushes. All trees that were measured by Dbh were numbered with indelible markers to facilitate their identification. Logging records (cutting, pruning, debarking, boring and bending) and the condition of the individuals measured were noted in order to inventory the pressure indicators.

\section{Characterization of Flora and Vegetation}

The analysis of the plant diversity focused on:

Specifics richness $(\mathrm{N}): \mathrm{N}=2^{\mathrm{H}} ; 2$ is the basis of the logarithm used to calculate the Shannon-Wiener's index $(\mathrm{H})$.

Shannon-Wiener's Index $(\mathrm{H}): \mathrm{H}=-\Sigma(\mathrm{ni} / \mathrm{Ni}) * \log _{2}$ (ni/Ni)

with $\mathrm{ni}=$ number of species $\mathrm{i}, \mathrm{Ni}=$ effective of all species; $\mathrm{H}$ is expressed in bit.

Piélou index (E): $\mathrm{E}=\mathrm{H} / \log _{2} \mathrm{~N}$.

with $\mathrm{a}=$ number of species in survey $1, \mathrm{~b}=$ number of species in survey $2, \mathrm{c}=$ number of species common to both surveys.

Simpson's diversity index $(\mathrm{Ds})=1-[(\mathrm{ni}(\mathrm{ni}-1)) /(\mathrm{N}(\mathrm{N}-1)]$.

Density (D): $\mathrm{D}=\mathrm{N} / \mathrm{S}$ D: Density (in trees/ha), N: Number of trees present on the surface considered and $S$ : surface area (ha).

Basal area $(\mathrm{Ba}): \mathrm{Ba}=\mathrm{di}^{2}(\mathrm{Pi} / 4)(\mathrm{di}=$ diameter, $\mathrm{Pi}=3.14)$.

Biovolume $(\mathrm{V})=0.53 \sum$ gi $\mathrm{x}$ hi $\mathrm{x}$ ni with gi: Basal area $\left(\mathrm{m}^{2} / \mathrm{ha}\right)$. Hi: height of the barrel $(\mathrm{m})$; ni: Number of individuals; $\mathrm{V}$ : biovolume $\left(\mathrm{m}^{3} / \mathrm{ha}\right)$.

Relative Frequency (RFi) was determined by using the formula: $\mathrm{RFi}=\mathrm{AFi} / \mathrm{TF} \times 100$ where $\mathrm{AFi}=$ Absolute 
frequency of species and TF $=$ Total Frequency $($ Sum of $\mathrm{AFi}$.

Relative Density (RDi) was determined by using the formula: $\mathrm{RDi}=\mathrm{ADi} / \mathrm{AD} \times 100$ where $\mathrm{ADi}=$ Absolute density of species and $\mathrm{AD}=$ Absolute density.

Relative Dominance or Cover (RCi) was determined by using the formula: $\mathrm{RCi}=\mathrm{BAi} / \mathrm{TBA} \times 100$ (Manohar, 2015).

Where $\mathrm{BAi}=$ Basal area of species and $\mathrm{TBA}=$ Total basal area.

Species Importance Value (SIV) of a species was calculated by adding the Relative Frequency (RFi), Relative Density (RDi) and Relative dominance (RCi).

The Family Importance Value Index (FIV) for botanical families was calculated by adding the IVI for different species of the same family.

Specific Importance of Regeneration (SIR) in $\%=$ Number of seedlings of a species/Total number of seedlings inventoried.

\section{Data Analysis}

The data have been encoded in the excel software and then analyzed using software Statgraphics plus 5.0. Testing the significance has been achieved thanks to the test of Duncan to $5 \%$.

\section{Results}

\section{Floristic Composition}

The total species richness recorded in the Sudanosehalian zone is 33 species in 20 families and 31 genera Table 1 . The agroforestry park based on A. leiocarpus is the richest in terms of floristic diversity Table 1 . The most represented families in terms of number of species are respectively Combretaceae (3 to 4 species), Caesalpiniaceae ( 2 to 3 species) and Mimosaceae ( 2 to 3 species) Table 1 . The average number of species per survey varies between $4.36 \pm 0.20$ and $4.98 \pm 0.29$ species depending on the park Table 1 .

\section{Diversity Indices and Structure}

The Shannon-Weiner index and Piélou equitability values are respectively less than 2.5 bits and 0.5 bits Table 2 .

Simpson's index tends towards 1 in all parks Table 2.

Recovery does not vary significantly across parks ( $\mathrm{p}>0.05$ ), with the highest recovery recorded in $P$. thonningii agroforestry parkland $(10.12 \pm 0.31 \%)$ Table 2 .

The density of individuals varies substantially between agroforestry parkland $(\mathrm{p}<0.025)$, with $A$. leiocarpus agroforestry parkland being the densest with an average of $223 \pm 8.01$ individuals/ha Table 2 .

Table 1: Specific richness

\begin{tabular}{|c|c|c|c|c|c|c|c|c|c|c|}
\hline Agroforestry parkland & \multicolumn{2}{|c|}{ A. leiocarpus } & \multicolumn{2}{|c|}{ I. doka } & \multicolumn{2}{|c|}{ T. laxiflora } & \multicolumn{2}{|c|}{ P. thonningii } & \multicolumn{2}{|c|}{ A. digitata } \\
\hline Number of species & \multicolumn{2}{|l|}{22} & \multicolumn{2}{|l|}{18} & \multicolumn{2}{|c|}{19} & \multicolumn{2}{|l|}{18} & \multicolumn{2}{|c|}{21} \\
\hline Number of genera & \multicolumn{2}{|l|}{21} & \multicolumn{2}{|l|}{17} & \multicolumn{2}{|l|}{19} & \multicolumn{2}{|l|}{18} & \multicolumn{2}{|l|}{20} \\
\hline Number of families & \multicolumn{2}{|l|}{13} & \multicolumn{2}{|l|}{10} & \multicolumn{2}{|l|}{13} & \multicolumn{2}{|l|}{11} & \multicolumn{2}{|l|}{12} \\
\hline Specific richness & \multicolumn{2}{|c|}{$4.98 \pm 0.29 \mathrm{a}$} & \multicolumn{2}{|c|}{$4.36 \pm 0.20 \mathrm{a}$} & \multicolumn{2}{|c|}{$4.57 \pm 0.24 \mathrm{a}$} & \multicolumn{2}{|c|}{$4.43 \pm 0.22 \mathrm{a}$} & \multicolumn{2}{|c|}{$4.76 \pm 0.27 \mathrm{a}$} \\
\hline Families & $\mathrm{Nb} . \mathrm{S}$ & $\%$ & $\mathrm{Nb} . \mathrm{S}$ & $\%$ & $\mathrm{Nb} . \mathrm{S}$ & $\%$ & $\mathrm{Nb} . \mathrm{S}$ & $\%$ & $\mathrm{Nb} . \mathrm{S}$ & $\%$ \\
\hline Anacardiaceae & 3 & 13.64 & 1 & 5.556 & 2 & 10.53 & 0 & 0 & 3 & 14.29 \\
\hline Annonaceae & 1 & 4.545 & 0 & 0 & 1 & 5.263 & 0 & 0 & 0 & 0 \\
\hline Bignoniaceae & 0 & 0 & 0 & 0 & 0 & 0 & 1 & 5.556 & 0 & 0 \\
\hline Bombacaceae & 1 & 4.545 & 0 & 0 & 1 & 5.263 & 0 & 0 & 0 & 0 \\
\hline Caesalpiniaceae & 3 & 13.64 & 2 & 11.11 & 2 & 10.53 & 3 & 16.67 & 3 & 14.29 \\
\hline Celastraceae & 0 & 0 & 0 & 0 & 1 & 5.263 & 1 & 5.556 & 1 & 4.762 \\
\hline Combreataceae & 4 & 18.18 & 4 & 22.22 & 3 & 15.79 & 3 & 16.67 & 4 & 19.05 \\
\hline Euphorbiaceae & 0 & 0 & 0 & 0 & 1 & 5.263 & 1 & 5.556 & 1 & 4.762 \\
\hline Fabaceae & 1 & 4.545 & 2 & 11.11 & 1 & 5.263 & 0 & 0 & 1 & 4.762 \\
\hline Mimosaceae & 3 & 13.64 & 2 & 11.11 & 3 & 15.79 & 3 & 16.67 & 2 & 9.524 \\
\hline Moraceae & 0 & 0 & 1 & 5.556 & 0 & 0 & 0 & 0 & 1 & 4.762 \\
\hline Myrtaceae & 1 & 4.545 & 0 & 0 & 0 & 0 & 0 & 0 & 1 & 4.762 \\
\hline Olacaceae & 0 & 0 & 1 & 5.556 & 0 & 0 & 1 & 5.556 & 0 & 0 \\
\hline Polygalaceae & 1 & 4.545 & 0 & 0 & 0 & 0 & 1 & 5.556 & 0 & 0 \\
\hline Rubiaceae & 0 & 0 & 2 & 11.11 & 1 & 5.263 & 2 & 11.11 & 2 & 9.524 \\
\hline Rhamanceae & 1 & 4.545 & 0 & 0 & 0 & 0 & 0 & 0 & 0 & 0 \\
\hline Sapotaceae & 0 & 0 & 1 & 5.556 & 1 & 5.263 & 0 & 0 & 1 & 4.762 \\
\hline Verbenaceae & 1 & 4.545 & 2 & 11.11 & 0 & 0 & 1 & 5.556 & 0 & 0 \\
\hline Total & 22 & 100 & 18 & 100 & 19 & 100 & 18 & 100 & 21 & 100 \\
\hline
\end{tabular}

The values assigned the same letter are not statistically different ( $>0.05$; Duncan test) 
Basal area and biovolume vary significantly between parks $(\mathrm{p}<0.05)$, with the highest recorded for $A$. leiocarpus agroforestry parkland $\left(\mathrm{Ba}=10.05 \pm 1.87 \mathrm{~m}^{2} / \mathrm{ha}\right.$ and $\mathrm{V}=38.54 \pm 0.76 \mathrm{~m}^{3} / \mathrm{ha}$ ) Table 2 .

The highest regeneration rate was observed in $A$. digitata agroforestry parkland with an average regeneration rate of $7.40 \pm 1.09 \%$ Table 2 .

The total height of Lorey did not vary significantly ( $p>0.05)$ between agroforestry parkland. The highest average total height of Lory was recorded in $A$. digitata agroforestry parkland with an average of $5.06 \pm 0.04 \mathrm{~m}$ Table 2 .

\section{Families Importance Value (FIV)}

The families with the highest FIV are respectively Combretaceae (50.32-69.91\%), Mimosaceae (40-60.65\%) and Caesalpiniaceae (34.89-66.4\%) Table 3.
Species Importance Value (SIV) and Specific Importance of Regeneration (SIR)

In the A. leiocarpus agroforestry parkland, Combretum glutinosum and Combretum adenogonium have the highest values of SIV with 30.76 and $30.67 \%$ respectively and SIR with 10.22 and $8.54 \%$ respectively. However, in the I. doka agroforestry parks, Sclerocarya birrea, Prosopis africana, Entada africana and Combretum adenogonium have the highest SIV values with $39.19,35.76,32.67$ and $30.76 \%$ respectively and SIR values with 12.60, 12.38, 11.38 and $8.88 \%$ respectively. On the other hand, in the $T$. laxiflora agroforestry parkland, Prosopis africana and Anacardium occidentale have the highest SIV values with 34.34 and $30.69 \%$ respectively and SIR values with 25.12 and $18.19 \%$ respectively.

Table 2: Diversity index and structure

\begin{tabular}{llllll}
\hline Agroforestry parkland & A. leiocarpus & I. doka & T. laxiflora & P. thonningii & A. digitata \\
\hline Shannon-Weiner index & $2 \pm 0.05 \mathrm{a}$ & $1.36 \pm 0.02 \mathrm{a}$ & $1.57 \pm 0.02 \mathrm{a}$ & $1.43 \pm 0.02 \mathrm{a}$ & $1.76 \pm 0.01 \mathrm{a}$ \\
Piélou equitability & $0.35 \pm 0.18 \mathrm{a}$ & $0.14 \pm 0.07 \mathrm{a}$ & $0.19 \pm 0.09 \mathrm{a}$ & $0,19 \pm 0.09 \mathrm{a}$ & $0.26 \pm 0.13 \mathrm{a}$ \\
Simpson index & $0.87 \pm 0.02 \mathrm{a}$ & $0.83 \pm 0.01 \mathrm{a}$ & $0.97 \pm 0.03 \mathrm{a}$ & $0.82 \pm 0.02 \mathrm{a}$ & $0.88 \pm 0.02 \mathrm{a}$ \\
Average recovery & $6.11 \pm 0.21 \mathrm{a}$ & $7.02 \pm 0.25 \mathrm{a}$ & $7.32 \pm 0.28 \mathrm{a}$ & $10.12 \pm 0.31 \mathrm{ab}$ & $6.76 \pm 0.23 \mathrm{a}$ \\
Density & $223 \pm 8.01 \mathrm{e}$ & $183 \pm 4.32 \mathrm{c}$ & $151 \pm 3.72 \mathrm{~b}$ & $108 \pm 2.98 \mathrm{a}$ & $201 \pm 6.01 \mathrm{~d}$ \\
Basal area & $8.54 \pm 1.45 \mathrm{~b}$ & $6.54 \pm 1.12 \mathrm{a}$ & $8.12 \pm 1.32 \mathrm{~b}$ & $10.05 \pm 1.87 \mathrm{c}$ & $6.76 \pm 1.20 \mathrm{a}$ \\
Biovolume & $23.43 \pm 2.66 \mathrm{ab}$ & $20.09 \pm 2.22 \mathrm{a}$ & $22.08 \pm 2.39 \mathrm{a}$ & $38.54 \pm 3.76 \mathrm{c}$ & $21.66 \pm 2.37 \mathrm{a}$ \\
Specific importance of regeneration & $2.11 \pm 0.52 \mathrm{a}$ & $3.12 \pm 0.62 \mathrm{~b}$ & $2.32 \pm 0.82 \mathrm{a}$ & $4.42 \pm 0.95 \mathrm{c}$ & $7.40 \pm 1.09 \mathrm{~d}$ \\
Height of Lorey $(\mathrm{m})$ & $2.11 \pm 0.01 \mathrm{a}$ & $2.52 \pm 0.02 \mathrm{a}$ & $4.32 \pm 0.03 \mathrm{ab}$ & $3.12 \pm 0.02 \mathrm{a}$ & $5.06 \pm 0.04 \mathrm{ab}$ \\
\hline
\end{tabular}

The values assigned the same letter are not statistically different ( $\mathrm{p}>0.05$; Duncan test)

Table 3: Families Importance Value (FIV)

\begin{tabular}{|c|c|c|c|c|c|}
\hline $\begin{array}{l}\text { Agroforestry parkland } \\
\text { Families }\end{array}$ & $\begin{array}{l}\text { A. leiocarpus } \\
\text { FIV }\end{array}$ & $\begin{array}{l}\text { I. doka } \\
\text { FIV }\end{array}$ & $\begin{array}{l}\text { T. laxiflora } \\
\text { FIV }\end{array}$ & $\begin{array}{l}\text { P. thonningii } \\
\text { FIV }\end{array}$ & $\begin{array}{l}\text { A. digitata } \\
\text { FIV }\end{array}$ \\
\hline Anacardiaceae & 42.12 & 12.43 & 40.87 & 11.00 & 34.72 \\
\hline Annonaceae & 11.54 & 0.00 & 11.23 & 11.00 & 0.00 \\
\hline Balanitaceae & 11.54 & 0.00 & 11.81 & 0.00 & 0.00 \\
\hline Bignoniaceae & 0.00 & 0.00 & 0.00 & 66.00 & 0.00 \\
\hline Bombacaceae & 19.54 & 0.00 & 11.11 & 11.00 & 0.00 \\
\hline Caesalpiniaceae & 42.43 & 40.00 & 35.92 & 66.40 & 34.89 \\
\hline Celastraceae & 0.00 & 0.00 & 11.00 & 11.00 & 12.65 \\
\hline Combreataceae & 56.54 & 50.32 & 60.65 & 0.00 & 69.91 \\
\hline Euphorbiaceae & 0.00 & 0.00 & 11.43 & 0.00 & 12.00 \\
\hline Fabaceae & 15.21 & 39.87 & 11.54 & 48.60 & 12.00 \\
\hline Meliaceae & 11.25 & 0.00 & 11.40 & 0.00 & 12.00 \\
\hline Mimosaceae & 42.43 & 40.86 & 60.65 & 0.00 & 40.00 \\
\hline Moraceae & 0.00 & 11.65 & 0.00 & 11.00 & 12.00 \\
\hline Myrtaceae & 11.87 & 0.00 & 0.00 & 11.00 & 12.00 \\
\hline Olacaceae & 0.00 & 12.54 & 0.00 & 42.00 & 0.00 \\
\hline Polygalaceae & 12.12 & 0.00 & 0.00 & 0.00 & 0.00 \\
\hline Rubiaceae & 0.00 & 39.91 & 11.50 & 0.00 & 36.34 \\
\hline Rhamanceae & 11.65 & 0.00 & 0.00 & 11.00 & 0.00 \\
\hline Sapotaceae & 0.00 & 12.87 & 10.89 & 11.00 & 11.49 \\
\hline Verbenaceae & 11.76 & 39.55 & 0.00 & 11.00 & 0.00 \\
\hline Total & 300.00 & 300.00 & 300.00 & 300.00 & 300.00 \\
\hline
\end{tabular}


Table 4: Species Importance Value (SIV) and Specific Importance of Regeneration (SIR)

\begin{tabular}{|c|c|c|c|c|c|c|c|c|c|c|}
\hline \multirow{2}{*}{$\begin{array}{l}\text { Agroforestry parkland } \\
\text { Species }\end{array}$} & \multicolumn{2}{|c|}{ A. leiocarpus } & \multicolumn{2}{|c|}{ I. doka } & \multicolumn{2}{|c|}{ T. laxiflora } & \multicolumn{2}{|c|}{ P. thonningii } & \multicolumn{2}{|c|}{ A. digitata } \\
\hline & SIV & SIR & SIV & SIR & SIV & SIR & SIV & SIR & SIV & SIR \\
\hline Anacardium occidentale & 20.56 & 6.83 & 0.00 & 0.00 & 30.69 & 18.19 & 0.00 & 0.00 & 11 & 2 \\
\hline Annona senegalensis & 1.34 & 1.84 & 0.00 & 0.00 & 10.34 & 0.80 & 0.00 & 0.00 & 0 & 0 \\
\hline Balanites aegyptiaca & 1.12 & 1.84 & 0.00 & 0.00 & 20.34 & 8.34 & 15.65 & 6.65 & 0 & 0 \\
\hline Burkea africana & 23.54 & 6.88 & 25.65 & 6.00 & 0.00 & 0.00 & 30.45 & 11.45 & 38 & 25 \\
\hline Ceiba pentandra & 10.43 & 3.84 & 0.00 & 0.00 & 18.69 & 0.60 & 0.00 & 0.00 & 0 & 0 \\
\hline Combretum glutinosum & 30.76 & 10.22 & 14.87 & 4.67 & 12.34 & 0.30 & 22.34 & 8.34 & 31 & 19 \\
\hline Dichrostachys cinerea & 26.00 & 7.54 & 0.00 & 0.00 & 9.34 & 1.34 & 10.98 & 1.98 & 11 & 2 \\
\hline Entada africana & 24.00 & 7.00 & 32.67 & 11.38 & 5.00 & 0.12 & 28.03 & 8.03 & 11 & 2 \\
\hline Erythrina senegalensis & 4.07 & 1.00 & 0.00 & 0.00 & 11.34 & 1.34 & 0.00 & 0.00 & 11 & 2 \\
\hline Eucalyptus camaldulensis & 4.04 & 1.84 & 15.00 & 3.74 & 0.00 & 0.00 & 0.00 & 0.00 & 11 & 2 \\
\hline Faidherbia albida & 10.76 & 2.69 & 0.00 & 0.00 & 4.34 & 0.30 & 10.65 & 1.65 & 0 & 0 \\
\hline Ficus glumosa & 0.00 & 0.00 & 22.30 & 5.68 & 0.00 & 0.00 & 20.00 & 10.00 & 30 & 18 \\
\hline Gardenia aqualla & 0.00 & 0.00 & 11.87 & 3.00 & 23.00 & 10.00 & 10.47 & 0.47 & 11 & 2 \\
\hline Khaya senegalensis & 7.20 & 5.00 & 0.00 & 0.00 & 4.34 & 0.30 & 0.00 & 0.00 & 11 & 2 \\
\hline Lannea acida & 8.87 & 3.74 & 0.00 & 0.00 & 0.00 & 0.00 & 0.00 & 0.00 & 11 & 2 \\
\hline Maytenus senegalensis & 0.00 & 0.00 & 0.00 & 0.00 & 10.34 & 0.80 & 30.45 & 11.45 & 11 & 2 \\
\hline Phyllanthus reticulatus & 0.00 & 0.00 & 0.00 & 0.00 & 10.34 & 0.84 & 10.56 & 0.56 & 1 & 1 \\
\hline Piliostigma reticulatum & 10.68 & 4.84 & 0.00 & 0.00 & 0.00 & 0.00 & 0.00 & 0.00 & 0 & 0 \\
\hline Prosopis africana & 0.00 & 0.00 & 35.76 & 12.38 & 34.34 & 25.12 & 10.00 & 2.00 & 0 & 0 \\
\hline Sarcocephalus latifolius & 0.00 & 0.00 & 13.65 & 1.50 & 0.00 & 0.00 & 7.41 & 7.41 & 11 & 2 \\
\hline Sclerocarya birrea & 8.98 & 1.54 & 39.19 & 12.60 & 4.34 & 0.30 & 0.00 & 0.00 & 11 & 2 \\
\hline Spathodea campanulata & 0.00 & 0.00 & 23.00 & 5.80 & 0.00 & 0.00 & 0.00 & 0.00 & 0 & 0 \\
\hline Strychnos spinosa & 22.65 & 5.54 & 0.00 & 0.00 & 21.34 & 11.30 & 10.46 & 0.46 & 0 & 0 \\
\hline Tamarindus indica & 10.65 & 3.84 & 10.02 & 2.88 & 11.00 & 1.50 & 1.13 & 1.13 & 11 & 2 \\
\hline Tectona grandis & 3.65 & 3.84 & 19.67 & 3.00 & 23.34 & 13.40 & 0.00 & 0.00 & 2 & 1 \\
\hline Terminalia glaucescens & 13.76 & 3.84 & 11.98 & 1.80 & 11.00 & 1.00 & 0.00 & 0.00 & 0 & 0 \\
\hline Terminalia macroptera & 10.98 & 1.38 & 18.95 & 4.38 & 12.69 & 2.60 & 10.02 & 1.02 & 11 & 2 \\
\hline Vitallaria paradoxa & 0.00 & 0.00 & 13.54 & 2.84 & 11.51 & 1.51 & 0.00 & 0.00 & 11 & 2 \\
\hline Vitex madiensis & 0.00 & 0.00 & 18.76 & 3.78 & 0.00 & 0.00 & 0.00 & 0.00 & 11 & 2 \\
\hline Total & 300.00 & 100.00 & 300.00 & 100.00 & 300.00 & 100.00 & 300.00 & 100.00 & 300 & 100 \\
\hline
\end{tabular}

Table 5: Anthropogenic and morphological factors

\begin{tabular}{llcccc}
\hline & Agroforestry parkland & & & \\
Anthropogenic factors & A. leiocarpus & I. doka & T. laxiflora & P. thonningii & A. digitata \\
\hline Cutting (\%) & 8.87 & 34.87 & 18.98 & 65.87 & 20.65 \\
Debarking (\%) & 5.76 & 1.76 & 45.87 & 1.76 & 40.00 \\
Pruning (\%) & 3.76 & 9.65 & 5.98 & 6.87 & 12.86 \\
Bending (\%) & 54.87 & 23.00 & 13.65 & 2.34 & 7.54 \\
Brilling (\%) & 10.65 & 12.76 & 8.76 & 0.76 & 3.76 \\
\hline
\end{tabular}

Next in the $P$. thonningii agroforestry parkland, Burkea africana and Maytenus senegalensis have the highest values of SIV with $30.45 \%$ each and SIR with $11.45 \%$ each, respectively. In the $A$. digitata agroforestry parkland, Burkea africana, Combretum glutinosum and Ficus glumosa have the highest SIV values with 38,31 and $30 \%$, respectively and SIR values with 25,19 and $18 \%$, respectively (Table 4).

The highest Cutting is recorded in the agroforestry parklands based on $P$. thonningii $(65.87 \%)$. The highest Debarking is recorded in the agroforestry parklands based on T. laxiflora (45.87\%). The highest Pruning is recorded in the agroforestry parklands based on $A$. digitata $(12.86 \%)$. The highest Bending is recorded in the agroforestry parklands based on A. leiocarpus (54.87\%).
The highest Brilling is recorded in the agroforestry parklands based on I. doka (12.76\%) (Table 5).

The diameter structure of the individuals shows that the number of individuals per diameter class decreases with increasing diameter. However, the most abundant individuals belong to the diameter class $\leq 10 \mathrm{~cm}$. The general distribution of the studied agroecosystems shows an exponential decreasing shape $(\mathbf{L})$ with a steep slope Fig. 2. The height structure illustrates the Gaussian "U" model. It shows a peak in the 4-6 m height class with $90 \%$ of individuals. Some individuals in the $8-10 \mathrm{~m}$ height class are poorly represented. On the other hand, the other height classes account for almost all individuals $(8 \%)$. These appear to be homogeneous and more or less evenly distributed Fig. 3. 


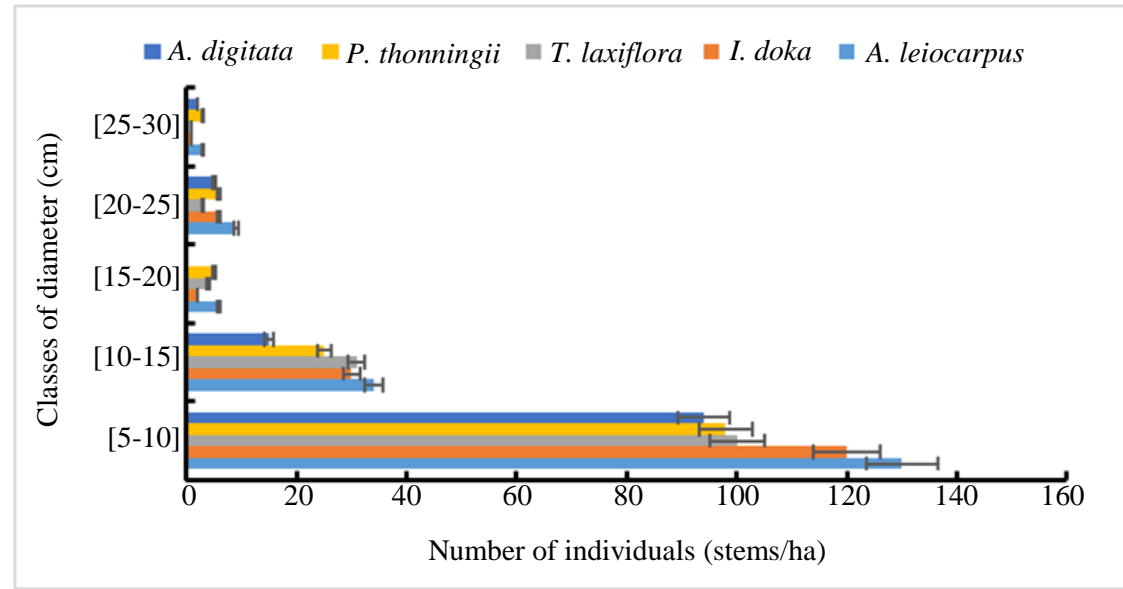

Fig. 2: Distribution by diameter class according to the number of individuals on agroforestry parkland. The values assigned the same letter are not statistically different $(\mathrm{p}>0.05$; Duncan test)

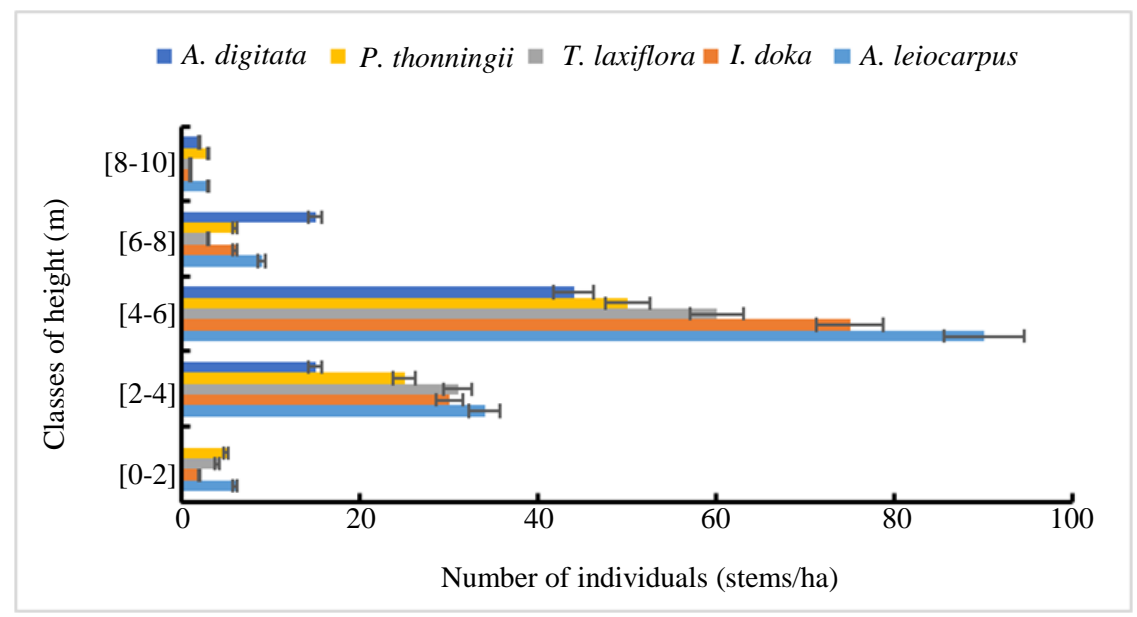

Fig. 3: Distribution by total height class according to the number of individuals on agroforestry parkland. The values assigned the same letter are not statistically different $(\mathrm{p}>0.05$; Duncan test)

\section{Discussion}

The floristic inventory identified a total of 33 woody species, divided into 31 genera and belonging to 20 families in the five agroforestry parks studied. This shows that the undergrowth in the agroforestry parks studied is very diversified. It is marked by a predominance of the family Combretaceae followed by those of Caesalpiniaceae and Mimosaceae in number of species. These results are comparable to those found by (Moussa et al., 2015; Morou et al., 2016; Manzo et al., 2017; Barmo et al., 2019; Konsala et al., 2020). The dominance of these families could be explained by the fact that most of the species in these families are better adapted to the climatic conditions and human activities in this Sudano-Sahelian zone. The predominance of these families in these zones could also be explained by the fact that these woody formations belong to the same climate type (Guimbo et al., 2010). The high floristic diversity recorded in the A. leiocarpus agroforestry parkland can be explained by their soil texture, which is very favourable to plant production. These results obtained during the present study are far from those of (Diedhiou et al., 2014) who found 54 species divided into 24 families and 43 genera in the agroforestry parks of the village of Mar Fafaco in the large island of Mar and (Kebenzikato et al., 2014) who found 52 species divided into 45 genera and 23 families in the Adansonia digitata L. (baobab) parks in Togo. They are however related to those of (Guimbo et al., 2010) who found 35 species in 33 genera and 20 families in the Vitellaria paradoxa parks, (Diatta et al., 2016) who found 35 species in 34 genera and 18 families in the agroforestry parks at Cordyla pinnata in the Southern Arachid Basin 
(Senegal); (Kaou et al., 2017) who found 38 species in 17 families and 32 genres in the dune area of south-eastern Niger and (Félix et al., 2019) who found 35 species in 32 genera and 17 families in the Sahelo-Sudanian zone of Niger. In general, the reduced number of woody species observed in I. doka; T. laxiflora; $P$. thonningii agroforestry parks would be linked to the strong selection and choice of plant species to be conserved, maintained or cut during field preparation (San Emeterio et al., 2013; Yameogo et al., 2013; Sina et al., 2016).

The Shannon-Weiner Index ranges from $1.36 \pm 0.14$ to $2 \pm 0.25$. High values of the Shannon Index show that all species are well represented and low values suggest a predominance of a few species over others (Dotchamou et al., 2016). This may be related to the fact that some species observed on sites with low Shannon index values evolve in stands and not as isolated individuals. These indices are comparable to those obtained by (Amani, 2016) in the agroforestry parks of Tamou (1.91 bits) and Simiri (1.24 bits) in western Niger; (Barmo et al., 2019) (1.38-1.73 bits) in agroforestry parks adjacent to the protected forest of Baban Rafi, Niger-West Africa. However, these indices are lower than those calculated in Guidan Roumdji by (Moussa et al., 2015) at the park level in Guiera senegalensis and Piliostigma reticulatum. The low diversity observed in these parks would also be linked to the strong pressure exerted by the population on the one hand and the precarious climatic conditions on the other hand. The Pielou index ranges from $0.14 \pm 0.07$ to $0.35 \pm 0.22$ bits, reflecting an overall low woody diversity for all parklands. These results are very similar to those obtained by (Barmo et al., 2019) in agroforestry parkland adjacent to the protected forest of Baban Rafi, Niger-West Africa. However, these indices are lower than those calculated by (Dotchamou et al., 2016) (0.56 and 0.94) in forest stands in Parkia biglobosa in Benin. These Pielou index revealed a dominance phenomenon in all zones. This can be explained by the difference in the adaptive capacities of certain species characteristic of a given climate, enabling them to rapidly colonize natural environments (Abdourhamane et al., 2013). Simpson's index tends towards 1 in all parks. This reflects the fact that these parks have a homogeneous distribution of its flora and that the probability of two randomly selected individuals belonging to the same species is high in these stands. The variation in plant diversity between zones is also dependent on population density and the edapho-climatic conditions of the region (Larwanou et al., 2012; Félix et al., 2019; Garba et al., 2020).

The values of the average recovery rates of the parks $(6.11 \pm 0.21$ to $10.12 \pm 0.31 \%)$, are higher than those of the parks in Sclerocarya birrea $(3.88 \%)$ in the Dan kada Dodo-Dan Gado classified forest complex (Abdourhamane et al., 2013). On the other hand, they are lower than those obtained in central southern Niger by (Moussa et al., 2015) in the parks at Faidherbia albida (29.49\%) and Prosopis africana (15.71\%). But are similar to those of (Barmo et al., 2019) (6.82 \pm 3.02 to $10.87 \pm 6.3 \%$ ) in agroforestry parks adjacent to the protected forest of Baban Rafi, Niger-West Africa. These differences could be due to the strong pressure (excessive logging, pruning, etc.) exerted by the population on these parks on the one hand and the presence of tall trees with large crowns on the other. Agroforestry parks based on A. leiocarpus are the densest with an average density of $223 \pm 8.01$ individuals/ha. This high density could be due to the effects of new clearings and the practice of assisted natural regeneration in the area. The lowest value is recorded at the level of agroforestry parks with $P$. thonningii $(108 \pm 2.98$ individuals/ha) located in the sedentary zone where these species are exploited by the populations to satisfy their daily needs.

The highest basal area and biovolume were recorded in the agroforestry parklands based on A. leiocarpus (Ba $=10.05 \pm 1.87$ and $\mathrm{V}=38.54 \pm 3.76 \mathrm{~m}^{3} / \mathrm{ha}$ ). This indicates the existence of large specimens of trees. Among the species in its undergrowth, some have a high shade rate. The high value of basal area $\left(\mathrm{Ba}=10.05 \pm 1.87 \mathrm{~m}^{2} / \mathrm{ha}\right)$ obtained in agroforestry parks based on A. leiocarpus is in the range $2.94 \pm 0.13-11.56 \pm 0.57 \mathrm{~m}^{2} /$ ha found by (Victor et al., 2019b) in savanna agrosystems in the Sudano-Sahelian zone of Cameroon. This means that these parks have an important timber potential due to their large diameters. These high biovolume values could be explained by the absence of human activities in these parks. The results obtained in this study are much lower than the $428.68 ; 285.57 ; 105.66 \mathrm{~m}^{3} /$ ha found respectively by (Kombate et al., 2019) in Agroforests, semi-deciduous dense forests and forest galleries and tree and shrub savannas of the Akposso Plateau in the sub-humid zone of Togo. On the other hand, are located in the ranges 30.84-202.72, 20.80-111.14, 30.05-58.11, 20.82-45.06 $\mathrm{m}^{3} /$ ha found respectively by (Victor et al., 2019a) to Khaya senegalensis, Burkea africana, Anogeissus leiocarpus, Piliostigma reticulatum Agroforestry parks in the Sudano-Sahelian zone of Cameroon. The highest regeneration rate was observed in agroforestry in $A$. digitata with an average regeneration rate of $10.12 \pm 0.31 \%$. This result is higher than those obtained by (Barmo et al., 2019) in agroforestry parks adjacent to the protected forest of Baban Rafi, Niger-West Africa. Tree regeneration processes can be influenced by factors such as mode of spread, viability, seed dormancy and predation (Bhadouria et al., 2016), water stress, soil structure, temperature, insect attacks, grazing which can delay the transition from juvenile to shrub stage (Sangare et al., 2016). The highest mean total height of Lory was recorded in A. digitata agroforestry parks with $5.06 \pm 0.04 \mathrm{~m}$. This result is similar to those obtained by (Barmo et al., 2019) in agroforestry parks 
adjacent to the protected forest of Baban Rafi, NigerWest Africa.

In A. leiocarpus agroforestry parks, Combretum glutinosum and Combretum adenogonium have the highest SIV and SIR values. However, in I. doka agroforestry parks, Sclerocarya birrea, Prosopis africana, Entada africana and Combretum adenogonium have the highest SIV and SIR values. On the other hand, in agroforestry parks with $T$. laxiflora, Prosopis africana and Anacardium occidentale have the highest SIV and SIR values. In the agroforestry parks of $P$. thonningii, Burkea africana and Maytenus senegalensis have the highest SIV and SIR values. In the agroforestry parks of $A$. digitata, Burkea africana, Combretum glutinosum and Ficus glumosa have the highest SIV and SIR values. The high SIV and SIR values of these species can be related to their high capacity of multiplication by vegetative voice and seed.

The distribution of individuals according to diameter classes varies from one park to another. It shows an inverted "J" curve in the different parks studied, reflecting a good natural regeneration of the parks' flora. This curve also shows a decrease in the number of individuals when the diameter of the individuals increases. This observation was made by in the agroforestry parks of Tamou terroir (Amani, 2016), in the Faidherbia albida parks of Dan Saga (Morou et al., 2016) and in the agroforestry parks of Baban Rafi (Barmo et al., 2019). The abundance of young individuals ensures the future of natural training since it allows a constant renewal of adult individuals. Such a structure is typical of stable populations that are likely to renew themselves through natural regeneration. The height class distribution has an " $U$ " bell structure centered on the height class [4-6 m], thus reflecting a predominance of medium height individuals. This situation is observed in an unstable population characterized by an absence or a very small proportion of individuals in one or more classes (Noumi et al., 2018; Victor et al., 2020b). It may be one of the consequences of recurring droughts due to the effects of strong pressure on fodder resources (Noumi et al., 2018; Victor et al., 2020b).

\section{Conclusion}

The present study allowed to characterize the woody vegetation of 05 agroforestry parks in the SudanoSahelian zone of Cameroon. This study found a total of 33 species distributed in 20 families and 31 genera found in all 05 agroforestry parks. These parks present variable specific and floristic diversities. These diversities are globally low, with a dominance of Sudanian species. The families Mimosaceae, Caesalpiniaceae, Combretaceae dominate in all the parks. The structure of the stands shows a predominance of young individuals for both diameter and height classes in all the parks. This structure also reveals a strong exploitation of large-diameter individuals. In view of these observations, these parks deserve special attention from decision-makers in order to provide appropriate solutions to guarantee their sustainability and the diversity of their function. In view of their social, ecological and environmental importance, such an agroforestry system is considered a factor in local development and the fight against climate change. Agricultural development services should therefore take an interest in the development of these agroforestry parks in order to motivate local communities to develop conservation strategies so that future generations can benefit from them.

\section{Acknowledgement}

We would like to thank all the referees whose contributions have been very important for the improvement of this manuscript.

\section{Author's Contributions}

Awé Djongmo Victor: Designed, collected and checked the analyzed data; prepared the draft manuscript and approved the final manuscript.

Noiha Noumi Valery and Zapfack Louis: Designed research plan and supervised this study.

\section{Ethics}

This article is original and contains unpublished material. The corresponding author confirms that all of the other authors have read and approved the manuscript and no ethical issues involved.

\section{References}

Abdourhamane, H., Morou, B., Rabiou, H., \& Amhamane, A. (2013). Caractéristiques floristiques, diversité et structure de la végétation ligneuse dans le Centre-Sud du Niger: cas du complexe des forêts classées de Dan kada Dodo-Dan Gado. International Journal of Biological and Chemical Sciences, 7(3), 1048-1068. https://doi.org/10.4314/ijbcs.v7i3.13

Amani, A. (2016). Croissance et potentiel de séquestration de carbone de quatre espèces de Combretaceae en zone sahélienne et nordsoudanienne au Niger (Afrique de l'Ouest) (Doctoral dissertation, Thèse de Doctorat en biologie et écologie végétales, Université Abdou Moumouni de Niamey, Niger).

Arbonnier, M. (2004). Trees, shrubs and lianas of West African dry zones. Montpellier: CIRAD-MNHN, 579 p. ISBN 2-85653-571-2; 2-87614-579-0. 
Barmo, S., Amani, A., Soumana, I., Ichaou, A., Karim, S., \& Mahamane, A. (2019). Structure et diversité des parcs agroforestiers adjacents à la forêt protégée de Baban Rafi, Niger-Afrique de l'Ouest. Afrique Science, 15(2), 166-185. http://www.afriquescience.net/PDF/15/2/15.pdf

Bhadouria, R., Singh, R., Srivastava, P., \& Raghubanshi, A. S. (2016). Understanding the ecology of treeseedling growth in dry tropical environment: a management perspective. Energy, Ecology and Environment, 1(5), 296-309. https://doi.org/10.1007/s40974-016-0038-3

Diatta, A. A., Ndour, N., Manga, A., Sambou, B., Faye, C. S., Diatta, L.,... \& Dieng, S. D. (2016). Services ecosystémiques du parc agroforestier à Cordyla pinnata (Lepr. ex A. Rich.) Milne-Redh. dans le Sud du Bassin Arachidier (Sénégal). International Journal of Biological and Chemical Sciences, 10(6), 2511-2525. https://doi.org/10.4314/ijbcs.v10i6.9

Diedhiou, M. A., Faye, E., Ngom, D., \& Toure, M. A. (2014). Identification et caractérisation floristiques des parcs agroforestiers du terroir insulaire de Mar Fafaco (Fatick, Sénégal). Journal of Applied Biosciences, 79, 6855-6866. https://doi.org/10.4314/jab.v79i0.11

Dotchamou, F. T., Atindogbe, G., Sode, A. I., \& Fonton, H. N. (2016). Density and spatial pattern of Parkia biglobosa under climate change: the case of Benin. $\mathbf{J}$ Agric Environ Int Dev, 110(1), 173-194.

FAO. (2015). Learning tool on nationally appropriate mitigation actions (NAMAs) in the agriculture, forestry and other land use (AFOLU) sector. Food and Agriculture Organization of the United Nations, Rome, Italy. 90p. http://www.fao.org/3/a-i4642e.pdf

Félix, ZCS, Tougiani, A., \& Moussa, M. (2019) Diversity and Structure of Woody Stands From Assisted Natural Regeneration (ANR) Following An Agro-Ecological Gradient In South Central Niger.

Froumsia, M., Zapfack, L., Mapongmetsem, P. M., \& Nkongmeneck, B. A. (2012). Woody species composition, structure and diversity of vegetation of Kalfou Forest Reserve, Cameroon. Journal of Ecology and the Natural Environment, 4(13), 333-343. https://doi.org/10.5897/JENE12.047

Garba, A., Amani, A., Douma, S., Sina, A. K. S., \& Mahamane, A. (2020). Structure des populations de Tamarindus indica L. dans la zone Sud-Ouest du Niger. International Journal of Biological and Chemical Sciences, 14(1), 126-142. https://doi.org/10.4314/ijbcs.v14i1.11

Guimbo, I. D., Mahamane, A., \& Ambouta, K. J. M. (2010). Peuplement des parcs à Neocarya macrophylla (Sabine) Prance et à Vitellaria paradoxa (Gaertn. CF) dans le sud-ouest nigérien: diversité, structure et régénération. International Journal of Biological and Chemical Sciences, 4(5). https://doi.org/10.4314/ijbcs.v4i5.65568
Kabore, E., Sambare, O., Ouedraogo, A., \& Thiombiano, A. (2013). Diversité et structure des cordons ripicoles le long de la sirba (Nord-Est du Burkina Faso). International Journal of Biological and Chemical Sciences, 7(5), 1929-1950. https://doi.org/10.4314/ijbcs.v7i5.13

Kaou, K. A. K., Manzo, O. L., Guimbo, I. D., Karim, S., Habou, R., \& Paul, R. (2017). Diversité floristique et structure de la végétation dans la zone dunaire du sud-est du Niger: Cas de Mainé soroa. Journal of Applied Biosciences, 120, 12053-12066.

https://www.ajol.info/index.php/jab/article/view/1 68743

Kebenzikato, A. B., Wala, K., Dourma, M., Atakpama, W., Dimobe, K., Pereki, H., ... \& Akpagana, K. (2014). Distribution et structure des parcs à Adansonia digitata L.(baobab) au Togo (Afrique de 1'Ouest). Afrique Science: Revue Internationale des Sciences et Technologie, 10(2). https://www.ajol.info/index.php/afsci/article/view/1 09682

Kombate, B., Dourma, M., Folega, F., Woegan, A. Y., Kpérkouma, W. A. L. A., \& Akpagana, K. (2019). Structure et potentiel de séquestration de carbone des formations boisées du Plateau Akposso en zone sub-humide au Togo. Afrique Science, 15(2), 70-79. http://www.afriquescience.net/AS/15/7.pdf

Konsala, S., Chimène, A. F., Désiré, W. B., \& Adamou, I. (2020) Floristic Composition of Woody Species and Potential Carbon Storage in Reforested Sites of Sudano-Sahelian Zone of Cameroon. https://doi.org/10.18535/ijsrm/v8i07.fe01

Larwanou, M., Moustapha, A. M., Rabe, M. L., \& Iro, D. (2012). Contribution de la Régénération Naturelle Assistée des ligneux dans l'approvisionnement en bois des ménages dans le département de Magaria (Niger). International Journal of Biological and Chemical Sciences, $6(1), \quad 24-36$. https://doi.org/10.4314/ijbcs.v6i1.3

Manohar, A. (2015). A Study on the Floristic Compositions of Hudguru Reserve Forest, Kodagu District, Karnataka, India. International Journal of Current Research and Academic Reviews, 3(9), 34-40.

Manzo, O. L., Garba, O. B., Morou, B., Karim, S., \& Mahamane, A. (2017). État de la végétation ligneuse au Sahel: Cas de Guidan Roumdji au sahel central du Niger. Journal of Animal \&Plant Sciences, 31(3), 5033-5049.

Morou, B., Ounani, H., Oumani, A. A., Diouf, A., Guero, C., \& Mahamane, A. (2016). Caractérisation de la structure démographique des ligneux dans les parcs agroforestiers du terroir de Dan Saga (Aguié, Niger). International Journal of Biological and Chemical Sciences, 10(3), 1295-1311. https://doi.org/10.4314/ijbcs.v10i3.31 
Mouhamadou, I. T., Imorou, I. T., Gbègbo, M. C., \& Sinsin, B. (2013). Structure et composition floristiques des forêts denses sèches de la région des Monts Kouffé au Bénin. Journal of Applied Biosciences, 64, 4787-4796. https://doi.org/10.4314/jab.v64i1.88467

Moussa, M., Mahamane, L., \& Saadou, M. (2015). Caractérisation des peuplements ligneux des parcs à Faidherbia albida (Del) A. Chev. et à Prosopis africana (Guill., Perrot et Rich.) Taub. du CentreSud Nigérien. Journal of Applied Biosciences, 94, 8890-8906. https://doi.org/10.4314/jab.v94i1.6

Noumi, V. N., Djongmo, V. A., Nyeck, B., Mbobda, R. B. T., \& Zapfack, L. (2018). Vegetation structure, carbon sequestration potential and species conservation in four agroforestry systems in Cameroon (Tropical Africa). Acta Botanica Brasilica, (AHEAD), 0-0. https://doi.org/10.1590/0102-33062017abb0279

Rabiou, H., Diouf, A., Bationo, B. A., Segla, K. N., Adjonou, K., Kokutse, A. D., ... \& Saadou, M. (2015). Structure Des peuplements naturels de pterocarpus erina-ceus poir. dans le domaine soudanien, au niger et au burkina faso. Bois \& Forets Des Tropiques, 325(325), 71-83. https://doi.org/10.19182/bft2015.325.a31274

San Emeterio, J., Alexandre, F., Andrieu, J., Génin, A., \& Mering, C. (2013). Changements socioenvironnementaux et dynamiques des paysages ruraux le long du gradient bioclimatique nord-sud dans le sud-ouest du Niger (régions de Tillabery et de Dosso). [VertigO] La revue électronique en sciences de l'environnement, 13(3). https://doi.org/10.4000/vertigo.14456
Sangare, G., Doka, D. I., Barrage, M., \& Fatondji, D. (2016). Contribution of previous legumes to soil fertility and millet yields in West African Sahel. African Journal of Agricultural Research, 11(28), 2486-2498. https://doi.org/10.5897/AJAR2016.11156

Sina, I. T., Chaibou, I., Ngom, D., Moussa, H., \& Banoin, M. (2016). Perception paysanne des ligneux à houppier fermé dans les agrosystèmes de Gaya: cas du terroir villageois de Tanda (République du Niger). Journal of Applied Biosciences, 106, 10309-10319. https://doi.org/10.4314/jab.v106i1.11

Victor, A. D., Valery, N. N., \& Louis, Z. (2019a). Carbon stocks in dead wood biomass of Savannah ecosystems in Northern Region Cameroon. J Bot Res, 2(1), 60-70. https://doi.org/10.36959/771/562

Victor, A. D., Valery, N. N., \& Louis, Z. (2019b). Vegetation structure, root biomass distribution and soil carbon stock of Savannah agrosystems in Sudano-Sahelian Zone of Cameroon. Journal Bot Research, 2(1), 71-80. https://doi.org/10.36959/771/563

Victor, A. D., Valery, N. N., \& Louis, Z. (2020a). Carbon storage and emission factor of Savanna ecosystems in soudano-sahelian zone of Cameroon. Journal Bot Research, 2(1), 60-67.

Victor, A. D., Valery, N. N., Chantal, M., \& Louis, Z. (2020b). Floristic composition, diversity and structure of Khaya senegalensis stands in Benue Department, Cameroon. Journal Trop. Resour. Sustain. Science 8, 60-68.

Yameogo, G., Yelemou, B., Boussim, I. J., \& Traore, D. (2013). Gestion du parc agroforestier du terroir de Vipalogo (Burkina Faso): contribution des ligneux à la satisfaction des besoins des populations. International Journal of Biological and Chemical Sciences, 7(3), 1087-1105. https://doi.org/10.4314/ijbcs.v7i3.16 